\title{
Expression of $L$-Selectin in Peripheral Blood Leukocytes of Crossbred Cows Affected with Subclinical Mastitis
}

\author{
Karthikeyan A. ${ }^{1 *}$, Radhika G. ${ }^{2}$ and Aravindakshan T.V. ${ }^{2}$ \\ ${ }^{1}$ Animal Genetics Division, ICAR-IVRI, Izatnagar, U.P, INDIA \\ ${ }^{2}$ Center for Advance Studies in Animal Genetics and Breeding, COVAS, KVASU, Mannuthy, Thrissur, Kerala, INDIA
}

"Corresponding author: A Karthikeyan; E-mail: karthikeyan0318@gmail.com

Received: 03 Feb., 2020

Revised: 19 Feb., 2020

Accepted: 23 Feb., 2020

\begin{abstract}
L-Selectin (SELL) linked with innate immune mechanism involved in neutrophil migration through endothelium to the site of inflammation. Early recruitment of neutrophils at the site of infection is essential to counteract infection at the earliest in conditions like sub-clinical mastitis (SCM). The present study was framed to evaluate the expression pattern of SELL in naturally occurring SCM in crossbred animals using real time PCR technique. Analysis of data on total leukocyte count indicated leucocytosis condition in SCM affected crossbred cows. Relative expression of SELL on peripheral blood leukocytes revealed a significant 3.16 folds down regulation in SCM affected cows when compared with healthy crossbred cows $(\mathrm{P}<0.05)$. The possible reason for leukocytosis in SCM animals might be due to down regulation of SELL on leukocytes reducing their ability to transmigrate through blood vessel to infection site. The result of present study revealed a definite role of SELL in SCM which could be explored for therapeutic aspects in near future.
\end{abstract}

Keywords: Sub clinical mastitis, L-Selectin, Crossbred cows, Gene expression, Peripheral blood leukocyte

Sub-clinical mastitis (SCM) emerges as a greater threat than clinical mastitis, due their carrier status of animals and unrecognized loss in milk production. Currently, combating strategies against mastitis include antibiotic therapy as treatment and strict sanitation methods as prevention. Development of vaccine against ended in failure, because developing a single vaccine giving prevention against multiple organisms is a difficult task. Alternative way to combat SCM is through utilizing animals own innate immune mechanism. To progress in such direction, one has to know the molecular mechanism of innate immune response during SCM condition. Innate immune response is considered to be a polygenic trait and so it is difficult to pin point upon any single gene corresponding to immune resistance. Innate immune mechanism forms the bottom line of defense in neutralizing constant threat of micro-organism invasion. Activation of innate immunity is essential to initiate subsequent adaptive immune responses. Early recruitment of neutrophils at the site of inflammation will reduce the severity of infection.
There are studies proving involvement of animal genetic makeup in disease susceptibility and resistance. SELL, a transmembrane molecule act as a molecular arm aiding in initial tethering of leukocytes to the site of inflammation. Ivetic et al. (2019) reported that L-Selectin (SELL), glycoprotein molecule highly expressed on the surface of all circulation leukocytes was essential for transmigration from blood stream to inflammatory site. According to Weber et al. (2001) glucocorticoids determine the level of SELL expression at mRNA level in parturient dairy cows. They also found that neutrophilia condition during glucocorticoid challenge was owed to down regulation of SELL expression in peripheral blood. Hence the present study was designed to evaluate the expression pattern of $S E L L$ in relation to resistance or susceptibility to SCM in crossbred cattle of Kerala.

How to cite this article: Karthikeyan, A., Radhika, G. and Aravindakshan, T.V. (2020). Expression of L-selectin in peripheral blood leukocytes of crossbred cows affected with subclinical mastitis. J. Anim. Res., 10(2): 299-302. 


\section{MATERIALS AND METHODS}

University Livestock Farm, Mannuthy formed the venue for this study. Six healthy crossbred cows, six SCM affected crossbred cows were selected as the experimental animals for this study. Blood samples were collected in six $\mathrm{mL} \mathrm{K}_{2}$ EDTA coated $\mathrm{BD}$ vacutainer under aseptic conditions. Total leukocytes count (TLC) were counted using haemocytometer under light microscope as per standard protocol. Total RNA was isolated from peripheral blood leukocytes using TRIzol ${ }^{\circledR}$ LS reagent (Life Technologies, USA). The RNA isolated was treated with deoxyribonuclease (DNase) enzyme amplification grade (Sigma-Aldrich) to remove DNA contamination in isolated total RNA, if any. First strand cDNA was synthesized using Revert Aid First strand cDNA synthesis kit (Thermo scientific). The primers used for target gene SELL was selected from karthikeyan et al. (2016) and reference gene $\beta$-actin was designed by using Primer3 (v.0.4.0) (Table 1). PCR efficiencies were calculated by using five-fold serially (six dilutions) diluted cDNA as template. Template concentration of 1,000 ng, $200 \mathrm{ng}, 40 \mathrm{ng}, 8 \mathrm{ng}, 1.6 \mathrm{ng}$ and $0.32 \mathrm{ng}$ were used to amplify each gene of interest under this study. PCR efficiencies were calculated automatically by inbuilt Eco ${ }^{\mathrm{TM}}$ Software v4.0.7.0 in Eco Real time PCR machine. About $250 \mathrm{ng}$ of isolated total RNA from blood samples were used for cDNA synthesis for target gene evaluation among two groups. The Cycle Threshold $\left(\mathrm{C}_{\mathrm{T}}\right)$ values obtained at the end of the reaction generated by the machine were recorded and further analysis was done based on $2^{-\Delta} \Delta \mathrm{C}_{\mathrm{T}}$ method (Livak and Schmittgen, 2001). Independent sample t-test was used for statistical analysis under SPSS V 21.0.

Table 1: Primer sequence used for qRT-PCR

\begin{tabular}{|c|c|c|c|}
\hline Name & Sequence $\left(5^{\prime} \rightarrow 3^{\prime}\right)$ & $\begin{array}{l}\mathrm{Tm} \\
\left({ }^{\circ} \mathrm{C}\right)\end{array}$ & $\begin{array}{l}\text { Expected } \\
\text { product size }\end{array}$ \\
\hline SELL-RT-F & $\begin{array}{l}\text { TACCATGGCCTGCA } \\
\text { CTCAC }\end{array}$ & 64.54 & \multirow{2}{*}{$150 \mathrm{bp}$} \\
\hline SELL-RT-R & $\begin{array}{l}\text { ACTCGACAGGTTGGT } \\
\text { TCTGG }\end{array}$ & 64.95 & \\
\hline
\end{tabular}

B-actin-RT-F GCATTGTTGGGTTCCTGT 60.70

\begin{tabular}{lll}
$\beta$-actin-RT-R & $\begin{array}{l}\text { TCACGAAGATCTGCA } \\
\text { TTTTG }\end{array}$ & $100 \mathrm{bp}$ \\
\hline
\end{tabular}

\section{RESULTS AND DISCUSSION}

Mean values of TLC of all three groups under this study are presented under table 2 . Independent sample t-test revealed a significant difference $(\mathrm{P}<0.01)$ between healthy crossbred and SCM affected crossbred cows. TLC in SCM affected crossbred cows indicates leukocytosis condition. Results of Singh et al. (2014) were also in accordance with this study, as they reported significantly higher values of TLC in SCM affected crossbred cows.

Table 2: Depicting the total leukocyte count among SCM and healthy crossbred cows

\begin{tabular}{lll}
\hline Parameter & $\begin{array}{l}\text { Healthy } \\
\text { crossbred cows }\end{array}$ & $\begin{array}{l}\text { SCM affected } \\
\text { crossbred cows }\end{array}$ \\
\hline $\begin{array}{l}\text { TLC }\left(\text { in } \times 10^{3} \text { cells } / \mu \mathrm{L}\right) \\
(\mathrm{n}=6)\end{array}$ & $9.15 \pm 0.35^{\mathrm{a}}$ & $11.48 \pm 0.91^{\mathrm{b} * *}$ \\
\hline
\end{tabular}

**-Significant at $\mathrm{P}$ value $<0.01$.

PCR efficiency was calculated for both the two genes (SELL and $\beta$-actin) under this study. Slope equation and $\mathrm{R}^{2}$ value corresponding for each gene of interest generated by Eco ${ }^{\mathrm{TM}}$ Software v4.0.7.0 were given in table 3. PCR efficiencies were found to be 94.42 per cent and 93 per cent, with high $\mathrm{R}^{2}$ value for $S E L L$ and $\beta$-actin, respectively.

Table 3: PCR efficiency for genes of interest

\begin{tabular}{llll}
\hline $\begin{array}{l}\text { Gene of } \\
\text { interest }\end{array}$ & $\begin{array}{l}\text { Standard curve } \\
\text { equation }\end{array}$ & $\begin{array}{l}\text { PCR efficiency } \\
(\%)\end{array}$ & $\mathbf{R}^{2}$ value \\
\hline SELL & $\mathrm{Y}=-3.46 \mathrm{x}+31.0$ & 94.42 & 0.988 \\
$\beta$-actin & $\mathrm{Y}=-3.50 \mathrm{x}+28.40$ & 93.00 & 0.988 \\
\hline
\end{tabular}

$\beta$-actin was used as internal control gene for studying expression pattern in peripheral blood cell, which showed stable expression level under this study. Cycle threshold $\left(\mathrm{C}_{\mathrm{T}}\right)$ of $\beta$-actin between assay groups showed lesser variation with standard deviation (SD) of 0.90 and coefficient of variation (CV) of 3.68 per cent. Melt curve analysis presented only single peak for each gene confirming absence of any non-specific product or primer dimer during qRT-PCR. Relative quantification of SELL in peripheral blood leukocytes revealed a significant 3.16 fold down regulation (P value $<0.05$ ) of SELL in SCM affected crossbred cows, when compared with healthy crossbred cows. Mean values of $\mathrm{C}_{\mathrm{T}}, \Delta \mathrm{C}_{\mathrm{T}}, \Delta \Delta \mathrm{C}_{\mathrm{T}}$ along with 
standard error and fold change in SELL expression under each group are given in table 4 .

Table 4: Mean $\mathrm{C}_{\mathrm{T}}$ values and fold change in SELL expression

\begin{tabular}{|c|c|c|c|c|c|}
\hline \multirow[b]{2}{*}{ Group } & \multicolumn{2}{|c|}{ Mean $C_{T} \pm S E$} & \multirow[b]{2}{*}{$\Delta \mathbf{C}_{\mathrm{T}}$} & \multirow[b]{2}{*}{$\Delta \Delta \mathbf{C}_{\mathrm{T}}$} & \multirow{2}{*}{$\begin{array}{l}\text { Fold } \\
\text { change } \\
\left(2^{-\Delta \Delta C}\right)\end{array}$} \\
\hline & SELL & $\beta$-actin & & & \\
\hline $\begin{array}{l}\text { Healthy } \\
\text { crossbred cows } \\
(n=5)\end{array}$ & $\begin{array}{l}23.50 \pm \\
0.27\end{array}$ & $\begin{array}{l}24.65 \pm \\
0.68\end{array}$ & $\begin{array}{l}-1.15 \pm \\
0.73\end{array}$ & $\begin{array}{l}0.00 \pm \\
0.73\end{array}$ & $\begin{array}{l}1^{\mathrm{b}} \\
(0.59- \\
1.66)\end{array}$ \\
\hline $\begin{array}{l}\text { SCM affected } \\
\text { crossbred cows } \\
(n=5)\end{array}$ & $\begin{array}{l}25.10 \pm \\
0.44\end{array}$ & $\begin{array}{l}24.58 \pm \\
0.16\end{array}$ & $\begin{array}{l}0.51 \pm \\
0.47\end{array}$ & $\begin{array}{l}1.66 \pm \\
0.47\end{array}$ & $\begin{array}{l}0.31^{\mathrm{a} *} \\
(0.22- \\
0.44)\end{array}$ \\
\hline
\end{tabular}

*-Significant at $\mathrm{P}$ value $<0.05$.

Multiple authors have reported usage of $\beta$-actin gene as internal control gene in case of expression studies from peripheral blood leukocytes (Weber et al., 2001; Matthews et al., 2015). Kozera and Rapacz (2013) suggested those internal control genes having standard deviation (SD) of CT values below one between inter-assays can be considered as most stable. Under this study $\beta$-actin was used as internal control gene which showed a SD of 0.90 and minimum coefficient of variation $(\mathrm{CV})$ of 3.5 per cent across different assays. The $\mathrm{R}^{2}$ values for all standard curves were 0.998 indicating the linearity of standard curves used for calculation of PCR efficiency. PCR efficiency calculated for each gene of interest had similar efficiency for both target and reference gene satisfying the assumption for relative quantification based on $2^{-\Delta \Delta C}$ method (Livak and Schmittgen, 2001). Expression pattern of SELL in peripheral blood leukocytes at transcriptomic level evaluated using qRT-PCR technique showed a significant 3.16 fold down regulation in SCM crossbred cows $(p<0.05)$ in relation to healthy crossbred cows. Leukocytosis condition noticed in SCM affected crossbred cows could be associated with down regulation of SELL in $\mathrm{SCM}$ crossbred affected cows. As leukocyte transmigration is impaired due to decreased SELL expression, this might lead to accumulation of leukocytes with in blood stream. Soltys and Quinn (1999) reported down regulation of SELL protein expression on peripheral blood leukocytes in Holstein cows infected with Staphylococcal and Streptococcal mastitis. Study conducted to quantify SELL protein expression on circulating polymorphonuclear leukocytes in endotoxin intra-mammary infusion showed a drastic $(\mathrm{P}<0.001)$ reduction in $S E L L$ expression (DiezFraile et al., 2003) and similar results were reported when challenged with $E$. coli infection (Diez-Fraile et al., 2004). Mukherjee et al. (2010) studied expression of SELL at protein level in naturally occurring clinical mastitis and confirmed a significant $(\mathrm{P}<0.05)$ decrease of $S E L L$ protein in mastitis cows in relation to healthy cows. Present study result was in discrepancy with Nagahata et al. (2011) who reported absence of significant difference in SELL expression on blood leukocytes in chronic $S$. aureus mastitis and healthy cows. Down regulation of SELL in SCM affected animals could be one of the possible causes for leukocytosis condition noticed, since down regulation of SELL leads to impaired transmigration of leukocytes to the site of infection.

\section{CONCLUSION}

Present study confirmed that SELL plays a definite role in innate immune response in case of SCM infection in crossbred cows. Further studies could be targeted using this molecule on preventive or therapeutic aspect.

\section{ACKNOWLEDGMENTS}

The authors are thankful to College of Veterinary and Animal Science, Mannuthy for the support of this research.

\section{REFERENCES}

Diez-Fraile, A., Mehrzad, J., Meyer, E., Duchateau, L. and Burvenich, C. 2004. Comparison of L-selectin and Mac-1 expression on blood and milk neutrophils during experimental Escherichia coli-induced mastitis in cows. Am. J. Vet. Res., 65: 1164-1171.

Diez-Fraile, A., Meyer, E., Duchateau, L. and Burvenich, C. 2003. L-Selectin and $\beta_{2}$-Integrin expression on circulating bovine polymorph nuclear leukocytes during endotoxin mastitis. J. Dairy Sci., 86: 2334-2342.

Ivetic, A., Hoskins Green, H.L. and Hart, S.J. 2019. L-selectin: a major regulator of leukocyte adhesion, migration and signaling. Frontiers Immunol., 10: 1068.

Karthikeyan, A., Radhika, G., Aravindhakshan, T. V. and Anilkumar, K. 2016. Expression profiling of innate immune genes in milk somatic cells during subclinical mastitis in crossbred dairy cows. Anim. Biotechnol., 27(4): 303-309. 
Kozera, B. and Rapacz, M. 2013. Reference genes in real-time PCR. J. Appl. Genet., 54: 391-406.

Livak, K.J. and Schmittgen, T.D. 2001. Analysis of relative gene expression data using Real-time quantitative PCR and the $2^{-\Delta \Delta C T}$ Method. Methods, 25: 402-408.

Matthews, D., Waters, M.S., Diskin, G.M., Kenny, D.A., Morris, D.G. and Earley, B. 2015. The effects of short term dietary restriction on haematological responses and leukocyte gene expression of anovulatory and ovulatory beef heifers. Res. Vet. Sci., 98: 145-153.

Mukherjee, R., Jadhav, K.R. and De, K.U. 2010. Expression of L-Selectin molecule on peripheral leukocyte in to nisin treatment during acute bovine mastitis. Veterinarski Arhiv., 80(3): $355-364$

Nagahata, H., Kawai, H., Higuchi, H., Kawai, K., Yayou, K. and Chang, J.C. 2011. Altered leukocyte responsiveness in dairy cows with naturally occurring chronic Staphylococcus aureus mastitis. J. Vet. Med. Sci., 73(7): 885-894.
Singh, R., Bhardwaj, R.K., Azad, M.S. and Beigh, S.A. 2014. Effect of mastitis on haemato-biochemical and plasma mineral profile in crossbred cattle. Indian J. Anim. Res., 48(1): 63-66.

Soltys, J. and Quinn, T.M. 1999. Selective recruitment of T-Cell subsets to the udder during Staphylococcal and Streptococcal mastitis: Analysis of Lymphocyte subsets and adhesion molecule expression. Infect. Immunol., 67(12): 6293-6302.

Weber, D.S.P., Madesen, A.S., Smith, W.O., Ireland, J.J. and Burton, L.J. 2001. Pre-translational regulation of neutrophil L-Selectin in glucocorticoid challenged cattle. Vet. Immunol. Immunopathol., 83: 213-240. 